\title{
ЕФЕКТИВНІСТЬ ПРАЦІ В АГРАРНИХ ПІДПРИЄМСТВАХ: ПОКАЗНИКИ, ТЕНДЕНЦІЇ, СТРАТЕГІЯ ПІДВИЩЕННЯ
}

\author{
Березіна Людмила Михайлівна \\ доктор економічних наук, професор, \\ Полтавська державна аграрна академія (м. Полтава, Україна) \\ ORCID 0000-0003-2843-5893 \\ I.berezina.poltava@gmail.com \\ Самойлик Юлія Васильовна \\ доктор економічних наук, доцент, \\ Полтавська державна аграрна академія (м. Полтава, Україна) \\ ORCID 0000-0003-1335-2331 \\ iuliia.samoilyk@gmail.com \\ Бодрий Ярослав Анатолійович \\ здобувач наукового ступеня доктора філософії за спеціальністю 051 Економіка \\ Полтавська державна аграрна академія (м. Полтава, Україна) \\ ORCID 0000-0003-1161-2638 \\ yaroslav.bodryy@pdaa.edu.ua
}

У статті набули подальшого розвитку рекомендації щодо підвищення ефективності праці в аграрних підприємствах. Виявлено особливості та роль праці в аграрному секторі економіки. Обгрунтовано, що продуктивність праці не тільки характеризує ефективність використання персоналу підприємства, а й показує загальні результати суспільного розвитку та рейтинг країни у світовому маситабі. Для діагностики ефективності використання персоналу у світовому масштабі проведено оцінювання таких показників, як виробництво ВВП за паритетом купівельної спроможності на одну особу та ВВП за паритетом купівельної спроможності на одну людино-годину. Виявлено лідерів серед країн Європи за ефективністю праці. До них належать Ірландія, Норвегія, Люксембург, Франиія, Нідерланди, Данія, Швейцарія, Швеція, Австрія, Великобританія. Проведено дослідження тенденцій ефективності праці в сільському господарстві. 3'ясовано, що у 2019 р. частка робітників, зайнятих у сільському господарстві в середньому по світу становила 26,9%, розраховано, що продуктивність праці в сільськогосподарських підприємствах України вдвічі нижча, ніж в Латвії та у 20 разів менше, порівняно із Данією. Обґрунтовано, що основною стратеаії підвищення ефективності праці в аграрних підприємствах має бути збалансований підхід до забезпечення економічної, соціально та екологічної ефрективності.

Ключові слова: ефективність пращі, продуктивність праці, ВВПза паритетом купівельної спроможності, галузева структура зайнятості, аграрне підприємство, стратегія підвищення ефективності праці.

DOI: https://doi.org/10.32845/bsnau.2019.4.21

Постановка проблеми. Персонал - це основна рушійна сила, яка забезпечує розвиток суб'єктів господарювання, незважаючи на рівень автоматизації, сфери функціонування, стадії життєвого циклу економічної системи. Незважаючи на високу якість інших ресурсів (земельних, фінансових, матеріальних), неефективне використання трудових ресурсів може звести нанівець всі зусилля, покладені на формування ресурсного потенціалу.

Особливе значення має праця в аграрному секторі економіки. По-перше, виробництво аграрної продукції має важливе значення для забезпечення населення світу в продуктах харчування та формування продовольчої безпеки на різних управлінських рівнях. По-друге, в аграрній сфері зайнята значна частина населення як окремих держав, так і світу в цілому. По-третє, не зважаючи на високий рівень інтенсифікації та автоматизації аграрної галузі та удосконалення технологічних процесів в цій сфрері, рівень використання ручної праці залишається досить високим. Ці та інші аспекти визначають актуальність пошуку дієвих механізмів підвищення ефективності праці в аграрних підприємствах, що забезпечить якісне зростання цієї галузі в цілому.

Аналіз останніх досліджень і публікацій, в яких за-

початковано розв'язання проблеми. Питання ефективності праці в аграрному секторі економіки привертають увагу низки науковців. Зокрема, привертають увагу дослідження таких науковців, як Бабенко А.Г., Богиня Д., Бикова А.Л., Бондаревська К.В., Буряк П., Волкова О., Грішнова О.б Кібанов А., Колот А., Крушельницька О., Лобза А.В., Лукашевич В.М., Михайлова Л.І., Маркіна І.А. Саблук П.Т., Семенова Л.Ю., Семикіна М., Шпак Н.А., та ін. Вивчення наукових праць дозволило сформувати висновок, що існують різні концептуальні підходи щодо обґрунтування ролі та значення персоналу в забезпеченні ефективного розвитку аграрних підприємств, а також показників, що характеризують ефективність праці та стратегічних механізмів її підвищення. Науковці розглядають сутність трудових ресурсів, трудового потенціалу, інтелектуального капіталу. Також приділяється увага методологічним підходам щодо оцінювання ефективності праці та показникам для її вимірювання. В економічній літературі також зустрічаються проектні роботи, у яких розглядаються питання формування механізмів підвищення ефективності використання персоналу. Однак, не зважаючи на значну кількість праць, у яких розглядаються окремі питання, пов'язані з ефективністю використання персоналу в аграрних підприємствах, в сучасній літературі відсутній єдиний комплексний концептуальний 
підхід щодо формування стратегії підвищення ефективності праці в аграрних підприємствах, що і визначає актуальність проведення досліджень у даному напрямі.

Постановка завдання. Метою дослідження $є$ виявлення основних тенденцій ефективності використання персоналу в аграрній сфері, оцінювання структури зайнятості за галузями, обґрунтування ролі персоналу в забезпеченні ефективності функціонування суб'єктів господарювання, формування стратегічних напрямів підвищення ефективності праці в аграрних підприємствах.

Методи дослідження. Для проведення дослідження використано монографічний, аналітичний, економіко-статистичний, графічний методи. Статистичною базою послугували дані Світового банку, Всесвітнього економічного форуму, Державного комітету статистики України.

Виклад основного матеріалу. Ефективність праці в сучасних умовах можна визначити як кількість економічних і соціальних благ, вироблених за певний проміжок часу належної якості у відповідності із нормами та стандартами використання трудових ресурсів. Оцінювати ефективність праці можливо за допомогою низки показників, які розраховуються на різних управлінських рівнях.

Так, І.Л. Петрова, розглядаючи ринок праці в цілому, формулює системоутворюючі показники: «рівень використання робочого часу (повний та неповний робочий час, співвідношення в межах певного сегменту); співвідношення попиту і пропозиції на послуги праці представників сегменту (виділено три ситуації: попит перевищує пропозицію; пропозиція перевищує попит; ринок праці збалансований); рівень доходів зайнятих у певному сегменті» [1, с. 137-138]. Ми цілком згодні з науковцем у тому, що зазначена система показників суттєво впливає на ефективність праці. Крім того, доцільно розглянути концептуальний підхід Т.О. Погорєлової, яка вважає, що «суттєвою особливістю категорії «ефрективність праці» $€$ те, що вона характеризує результативність живої праці як діяльності людей, усіх її видів і всієї сукупної праці суспільства, а також усіх її складових; категорія «ефективність праці» має соціальний аспект, який у цивілізованих країнах набуває виключно важливого значення; проблема підвищення ефективності праці полягає в досягненні певної мети з мінімальними затратами праці; останнє виступає однією 3 економічних закономірностей суспільства, що зумовлена зростаючими потребами громадян у матеріальних і духовних благах, необхідністю їх задоволення в умовах обмеження виробничих ресурсів» [2, с. 17].

Рижих В. і Морозова Н. пов'язують ефективність функціонування ринку праці із структурою зайнятості. Науковці зазначають, що «перспективи розвитку національного ринку праці, а отже, формування ефективної структури зайнятості на територіальному та міжгалузевому рівнях залежать від вибору сценаріїв розвитку національного ринку праці, один 3 яких передбачає формування моделі, що базується на використанні ресурсних конкурентних переваг, інший - на мобілізації чинників інноваційного розвитку. Вибір першого сценарію розвитку неминуче призведе до підвищення ризиків консервації моделі «дешевої робочої сили», збереження значної частки неконкурентоспроможних робочих місць та неефективного використання трудового потенціалу. Другий сценарій відкриває нові перспективи для економічного зростання, але водночас потребує значних зусиль щодо реструктуризації зайнятості, збільшення частки інноваційних робочих місць у промисловості, сфері послуг, транспорті та сільському господарстві» [3, с. 91].

Цікавими є дослідження І.А. Маркіної та О.О. Михайлова, в контексті дослідження проблем проблеми якості кадрового потенціалу підприємства, науковці підкреслюють важливість формування ефективної кадрової політики, «яка повинна не лише містити методи і засоби управління кадрами, але і визначати потребу у фахівцях, формувати резерв висококваліфікованих працівників; адже у світовій практиці господарювання, навіть в умовах кризи, власники та менеджери займаються не тільки «переманюванням високопродуктивних фахівців», але і їх продажем («аутстаффінгом») та аутсорсингом» [4, с. 73]. Ми підтримуємо точку зору науковців і вважаємо, що кадрова політика $є$ визначальним чинником, що забезпечує підвищення ефективності праці в будь-якому підприємстві.

Більшість науковців схиляються до того, що основним показником, який виражає ефективність праці є ї̈ продуктивність. На думку І. Танасюк, О. Орленко, «із дослідженням продуктивності праці пов'язані розуміння суті та значущості соціально-економічного прогресу, оцінка ефективності і перспектив розвитку економіки в цілому та економіки підприємства зокрема; рівень і динаміка продуктивності праці наочно показують потенційні можливості підприємства для реалізації соціально-економічних цілей як в найближчому майбутньому, так і у віддаленій перспективі» [5, с. 182]. Також О.М. Орленко підкреслює, що «проблема зростання продуктивності праці завжди займала вагоме місце в умовах будь-якої суспільноекономічної формації; саме з її дослідженням пов'язують розуміння сутності та значущості соціально-економічного прогресу, оцінку ефективності та перспектив розвитку економіки; рівень продуктивності праці слугує яскравим індикатором існуючих та майбутніх перспектив та можливостей підприємства та суспільства» [6, с. 94].

Отже, продуктивність праці не тільки характеризує ефективність використання персоналу підприємства, а й показує загальні результати суспільного розвитку та рейтинг країни у світовому масштабі. Більшість країн з розвиненої ринковою економікою досягли досить високих значень виробництва продукції в розрахунку на одного працівника. Це забезпечило високий рівень ефективності господарської діяльності як окремих підприємств, так і національної економіки в цілому. Разом з тим, такі тенденції мають негативні соціальні наслідки, а саме: у зв'язку з високим рівнем автоматизації виробництва та зростання продуктивності праці суттєво зменшується потреба в персоналі. Таким чином, виникає загроза безробіття. Тому зростання продуктивності праці повинне забезпечувати як економічний, так і соціальний ефект. Для оцінювання ефективності використання персоналу у світовому масштабі доцільно проаналізувати такі показники, як виробництво ВВП за паритетом купівельної спроможності на одну особу та ВВП за паритетом купівельної спроможності на одну людино-годину (рис. 1).

Діагностика даних показників також $є$ актуальною для оцінювання рівня глобалізаційного розвитку країн світу [7]. На рис. 1 представлено європейські країни - лідерами за показниками ефективності використання персоналу. Серед досліджуваних країн перше місце за показником ВВП за ПКС на одну людино-годину займає Ірландія (79,48 тис. дол.), на другому місці за цим показником знаходиться Норвегія (77,85 тис. дол.), при цьому, дана країна посідає перше місце 
за ВВП за ПКС на одну особу. Крім того, в обох рейтингах лідируючі позиції займають такі країни, як Люксембург, Франція, Нідерланди, Данія, Швейцарія, Швеція, Австрія, Великобританія. Тобто високі показники ефективності праці спостерігаються саме в тих країнах, які володіють прогресивними інноваційними технологіями, багатогалузевою промисловістю, мають високий ступінь автоматизації виробництва та високі якісні показники персоналу (рівень освіти, кваліфікація, інтелектуальний рівень).

Країни
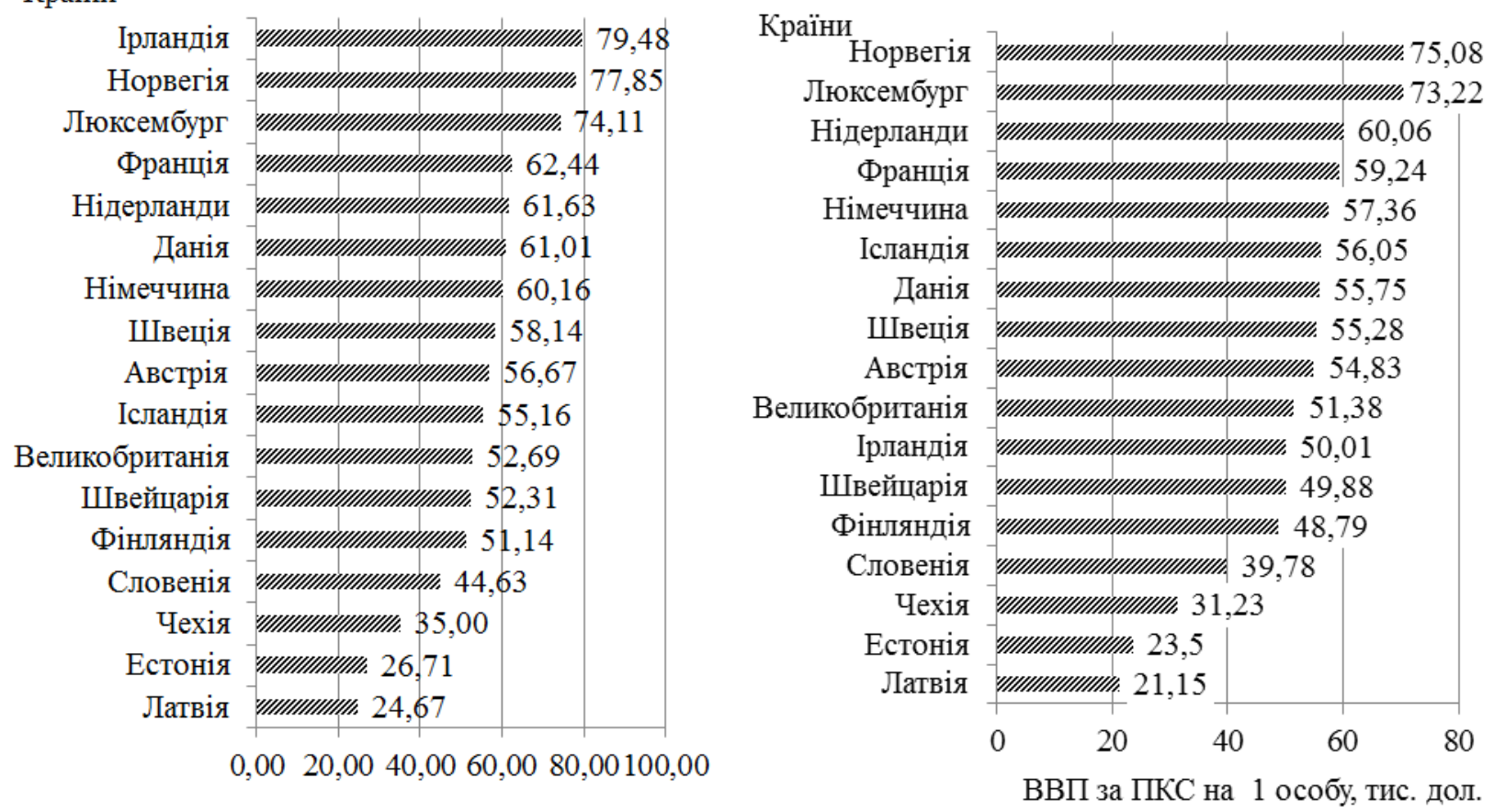

ВВП за ПКС на 1 люд.-год., тис. дол.

Рис. 1. Показники ефективності праці в розрізі європейських країн - лідерів за ВВП за паритетом купівельної спроможності на одну особу та одну людино-годину, 2019 p.

Джерело: узагальнено автором за [8, 15, 28]

Показник ефективності праці в розрізі країн залежить від галузей, які $є$ визначальними для розрахунку агрегованих показників, зокрема таких, як ВВП. Так, наприклад, високотехнологічні галузі дозволяють забезпечити значне зростання продуктивності праці, відповідно ті сфери, які потребують ручної праці, не забезпечують високих приростів даного показника. Крім того, ефективність праці коливається залежно від розмірів суб'єктів господарювання, які забезпечують створення ВВП: чим більше підприємство, тим можливе вище досягнення показників продуктивності праці за рахунок ефекту масштабу виробництва; якщо в економіці країни присутні дрібні виробники, то і зростання продуктивності праці здебільшого ускладнюється через переважання дрібносерійного виробництва. Разом з тим, продукція, виготовлена мануфактурним способом, $є$ більш цінною, і тому розрахунок продукти- вності праці шляхом ділення обсягів виробництва у грошовому виразі на чисельність працівників або кількість затраченого часу на виробництво даної продукції матиме високі значення. Отже, порівнювати показники ефективності праці залежно від розміру підприємства доцільно лише у тих випадках, якщо виробляються ідентичні товари.

Значної уваги потребує ефективність праці в сільському господарстві. У даній галузі зайнята значна частка населення у світі, у деяких країнах (здебільшого тих, що розвиваються), цей показник становить понад $90 \%$. Крім того, зайнятість у сільському господарстві має не лише економічне, а й соціальне значення, оскільки забезпечує роботу сільське населення та сприяє розвитку сільських територій. Разом з тим, можемо побачити суттєве скорочення частки зайнятих у сільському господарстві в останні роки (рис. 2). 
Частка, \%

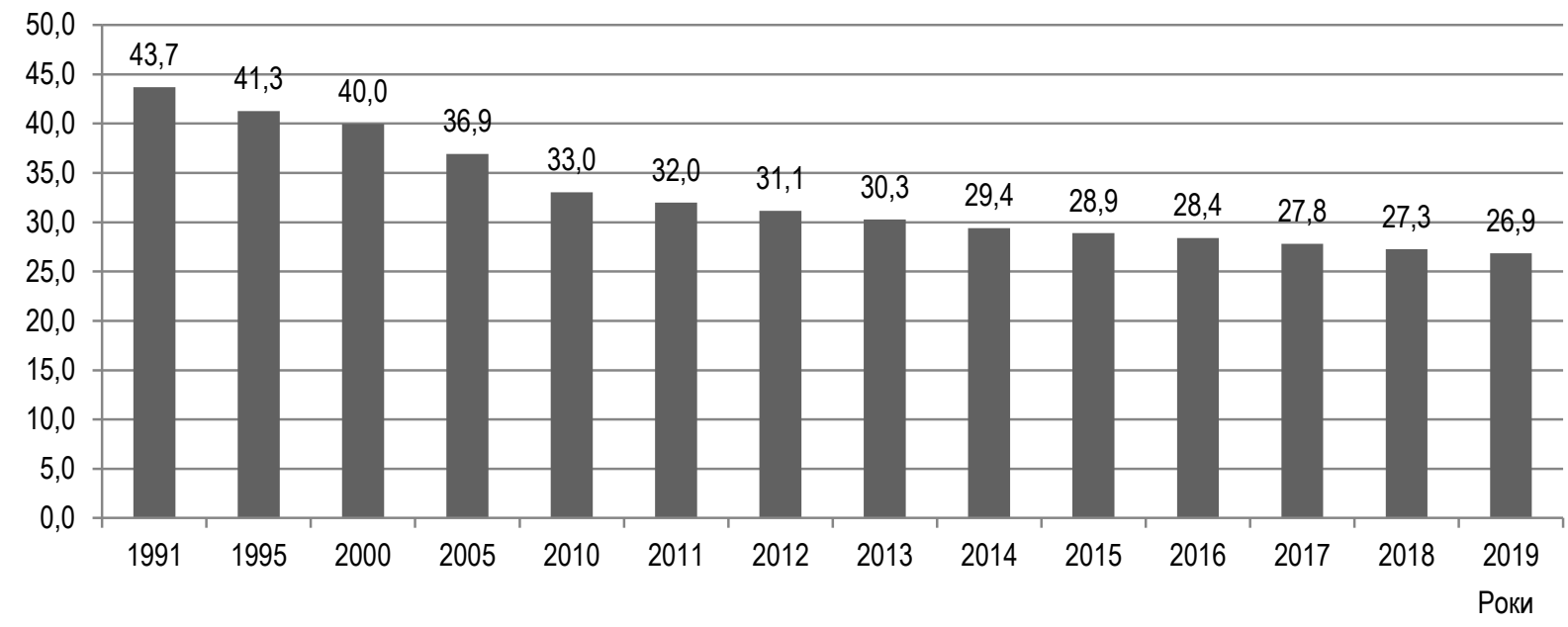

Рис. 2. Частка робітників, зайнятих у сільському господарстві у світі,

Джерело: узагальнено автором за [8, 15, 28]

1991-2019 рр., \%

У 2019 р. частка робітників, зайнятих у сільському господарстві в середньому по світу становила 26,9\%, це на 16,8 п.п. менше, ніж у 1991 р. За 18 останніх років спостерігалась стійка тенденція до скорочення даного показника. Ці зміни пов'язані із суттєвим підвищенням рівня механізації та автоматизації в сільському господарстві. Насамперед, скорочення потреби в персоналі можна спостерігати при використанні техніки: широкозахватні сівалки, безпілотні технології,

системи точного внесення та GPS-навігації дозволяють виконувати точніше, оперативніше та ефективніше стандартний набір технологічних операцій у сільському господарстві 3 меншою потребою в персоналі.

Якщо розглянути європейські країни, які є лідерами за загальними показниками ефективності праці (див. рис. 1), то можна простежити закономірність серед усіх країн зменшення частки зайнятих у сільському господарстві (табл. 1).

Таблиця 1

Показники динаміки частки сільського господарства у країнах Європи, 2014-2019 рр., \%

\begin{tabular}{|l|c|c|c|c|c|c|c|}
\hline \multicolumn{1}{|c|}{ Країни } & 2014 p. & 2015 p. & $2016 \mathrm{p}$. & $2017 \mathrm{p}$. & $2018 \mathrm{p}$. & $2019 \mathrm{p}$. & 2019 р. від 2014,+,- \\
\hline Данія & 2,483 & 2,497 & 2,532 & 2,21 & 2,243 & 2,186 & $-0,297$ \\
\hline Нідерланди & 2,292 & 2,32 & 2,262 & 2,268 & 2,098 & 2,035 & $-0,257$ \\
\hline Бельгія & 1,218 & 1,177 & 1,251 & 1,164 & 0,994 & 0,961 & $-0,257$ \\
\hline Швейцарія & 3,578 & 3,439 & 3,362 & 3,109 & 3,03 & 2,949 & $-0,629$ \\
\hline Люксембург & 1,426 & 1,045 & 1,026 & 1,389 & 1,054 & 1,007 & $-0,419$ \\
\hline Ісландія & 4,535 & 4,239 & 3,895 & 3,757 & 4,03 & 3,938 & $-0,597$ \\
\hline Німеччина & 1,428 & 1,394 & 1,308 & 1,277 & 1,249 & 1,21 & $-0,218$ \\
\hline Швеція & 1,975 & 2,037 & 1,886 & 1,831 & 1,699 & 1,648 & $-0,327$ \\
\hline Норвегія & 2,25 & 2,01 & 2,09 & 2,063 & 2,105 & 2,055 & $-0,195$ \\
\hline Великобританія & 1,255 & 1,137 & 1,124 & 1,159 & 1,07 & 1,034 & $-0,221$ \\
\hline Франція & 2,845 & 2,745 & 2,872 & 2,629 & 2,508 & 2,443 & $-0,402$ \\
\hline Фінляндія & 4,256 & 4,224 & 3,865 & 3,763 & 3,712 & 3,606 & $-0,65$ \\
\hline Австрія & 4,837 & 4,531 & 4,348 & 3,93 & 3,694 & 3,581 & $-1,256$ \\
\hline Чехія & 2,749 & 2,925 & 2,901 & 2,803 & 2,802 & 2,718 & $-0,031$ \\
\hline Естонія & 3,858 & 3,902 & 3,894 & 3,526 & 3,294 & 3,184 & $-0,674$ \\
\hline Ірландія & 5,442 & 5,337 & 5,285 & 5,048 & 4,77 & 4,619 & $-0,823$ \\
\hline Словаччина & 3,498 & 3,179 & 2,887 & 2,708 & 2,293 & 2,184 & $-1,314$ \\
\hline Литва & 9,166 & 9,069 & 7,976 & 7,784 & 7,183 & 6,873 & $-2,293$ \\
\hline Латвія & 7,504 & 7,939 & 7,692 & 6,868 & 6,972 & 6,75 & $-0,754$ \\
\hline
\end{tabular}

Джерело: узагальнено автором за $[8,15,28]$

Частка зайнятих у сільському господарстві у європейських країнах, які є лідерами за рівнем ефективності праці, коливається з 0,961 \% у Бельгії до 6,873 \% у Литві, тобто є зовсім незначною. При цьому, у всіх досліджуваних країнах протягом 2014-2019 рр. спостерігається скорочення даного показника. Найбільше даний показник скоротився в Словаччині - на 1,314 п.п. та Австрії - на 1,256 п.п. що стосується кількісних значень продуктивності праці у європейських країнах лідерах за ефективністю праці, то найвищою продуктивність праці у сільському господарстві спостерігається в Данії - 216,68 млн. євро на одного робітника (рис. 3). 


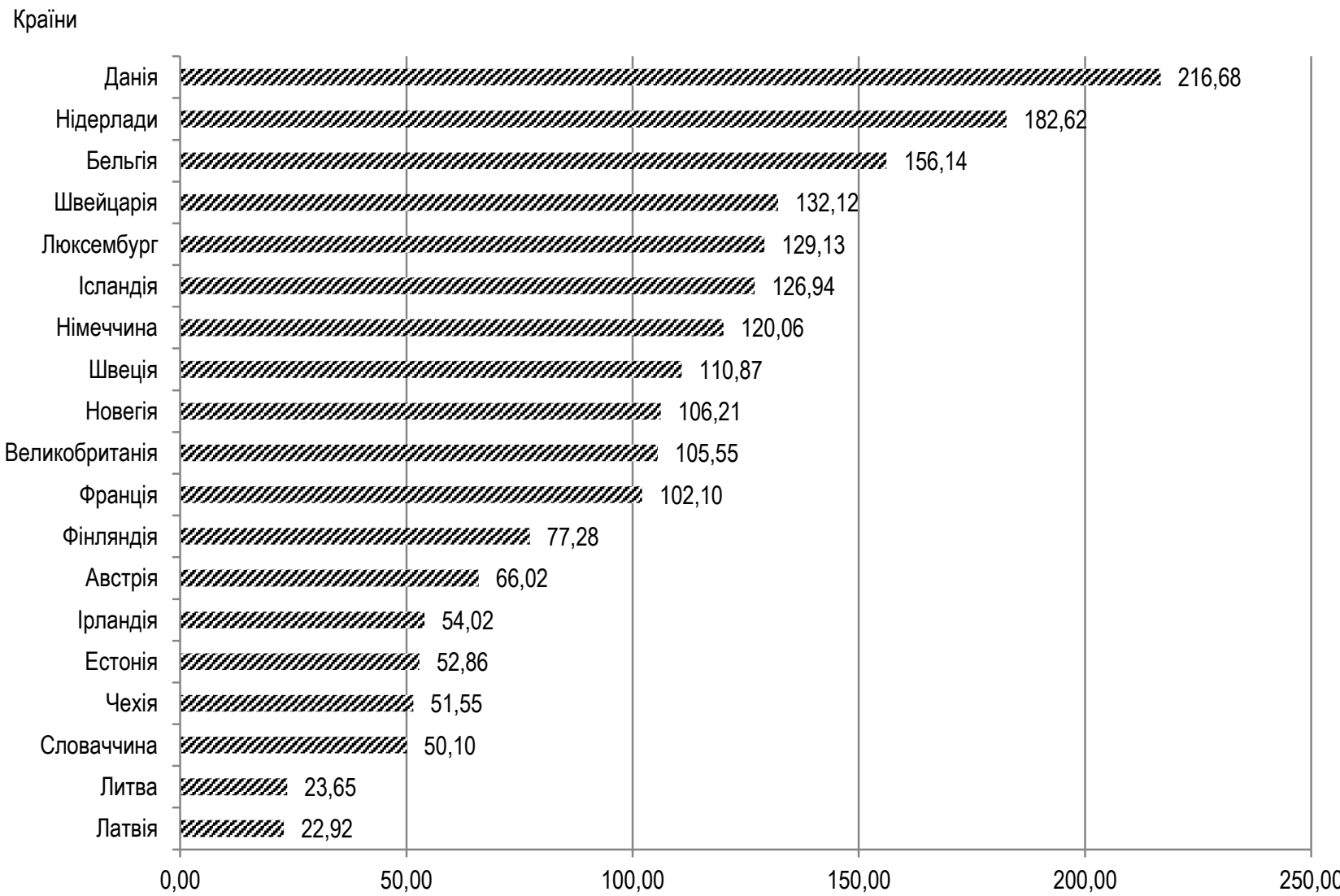

Продуктивність праці в сільському господарстві, тис. євро на 1 робітника

Рис. 3. Продуктивність праці в сільському господарстві у європейських країнах, які є лідерами за ефективністю праці, 2019 р.

Джерело: узагальнено автором за $[8,15,28]$

Високі показники продуктивності праці в сільському господарстві досягнуті також в Нідерландах (182,62 млн. євро/1 робітника) та Бельгії (156,14 млн. євро/1 робітника). Для пострадянських країн, які все ж потрапляють до рейтингу, показники продуктивності праці в рази нижчі: Литва - 23,65 млн. євро/1 робітника, Латвія - 22,92 млн. євро/1 робітника. Розвиток технологій та активне впровадження досягнень науково-технічного прогресу у сільськогосподарську ссреру в країнах з розвинутою ринковою економікою прямо пропорційне зростанню продуктивності праці. Разом з тим, потребують уваги показники якості кінцевої продукції. Активне використання прогресивних технологій виробництва сільськогосподарської продукції забезпечує зниження витрат, у тому числі і трудових, що досягається за рахунок надмірної хімізації, впровадження генної інженерії тощо, при цьому, якісні характеристики кінцевої продукції знижуються.

Характеризуючи ефективність праці в сільському господарстві України, варто зазначити, що частка зайнятих у даній сфрері наразі становить 18 \%. Це 2937,6 млн. осіб (рис. 4). Найбільша частка населення України працює у сорері оптової та роздрібної торгівлі; ремонті автотранспортних засобів і мотоциклів - 3654,7 млн. осіб, або $22 \%$. У промисловості зайнято 2426 млн. осіб, або $15 \%$. Порівняно висока частка українців працює в системі освіти - 1416,5 млн. осіб, або $9 \%$. В інших сфрерах зайнято від $1 \%$ до $6 \%$ усього населення. Така структура зайнятості не характерна для європейських країн, у яких більшість населення працюють в промисловості, фрінансовій системі, сфері послуг (зокрема інтелектуальних). 


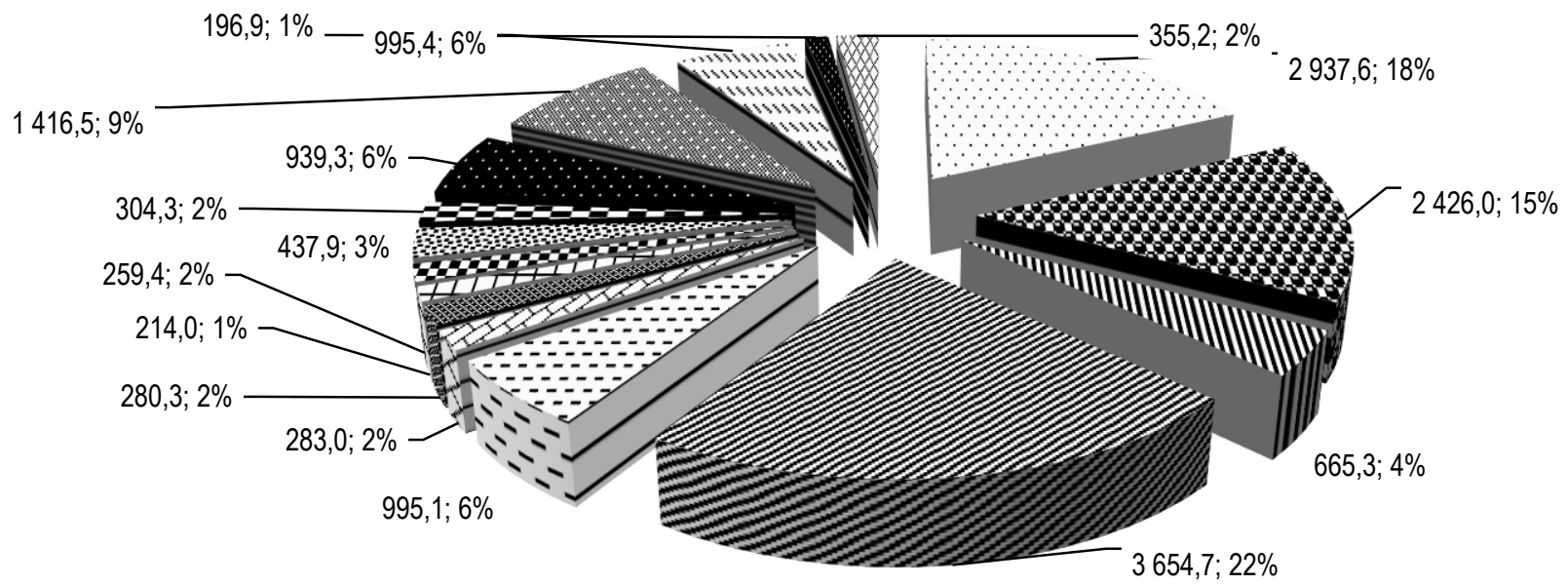

. сільське господарство, лісове господарство та рибне господарство

промисловість

І будівництво

乙 оптова та роздрібна торгівля; ремонт автотранспортних засобів і мотоциклів

$\therefore$ транспорт, складське господарство, поштова та кур'єрська діяльність

‘ тимчасове розміщування й організація харчування

інформація та телекомунікації

Г фінансова та страхова діяльність

п операції з нерухомим майном

професійна, наукова та технічна діяльність

n діяльність у сфері адміністративного та допоміжного обслуговування

п державне управління й оборона; обов'язкове соціальне страхування

\% освіта

“ охорона здоров'я та надання соціальної допомоги

мистецтво, спорт, розваги та відпочинок

$x$ інші види економічної діяльності

Рис. 4. Структура зайнятості населення України за видами економічної діяльності, 2018 р., млн. осіб; \% Джерело: узагальнено автором за [10]

Оцінюючи продуктивність праці в сільськогосподарських підприємствах України, варто зазначити, що вона вдвічі нижча, ніж в Латвії, яка займає останню позицію в рейтингу Індекс, \%

європейських країн за цим показником та у 20 разів менше, порівняно із Данією, яка є абсолютним лідером і даному рейтингу (рис. 5).

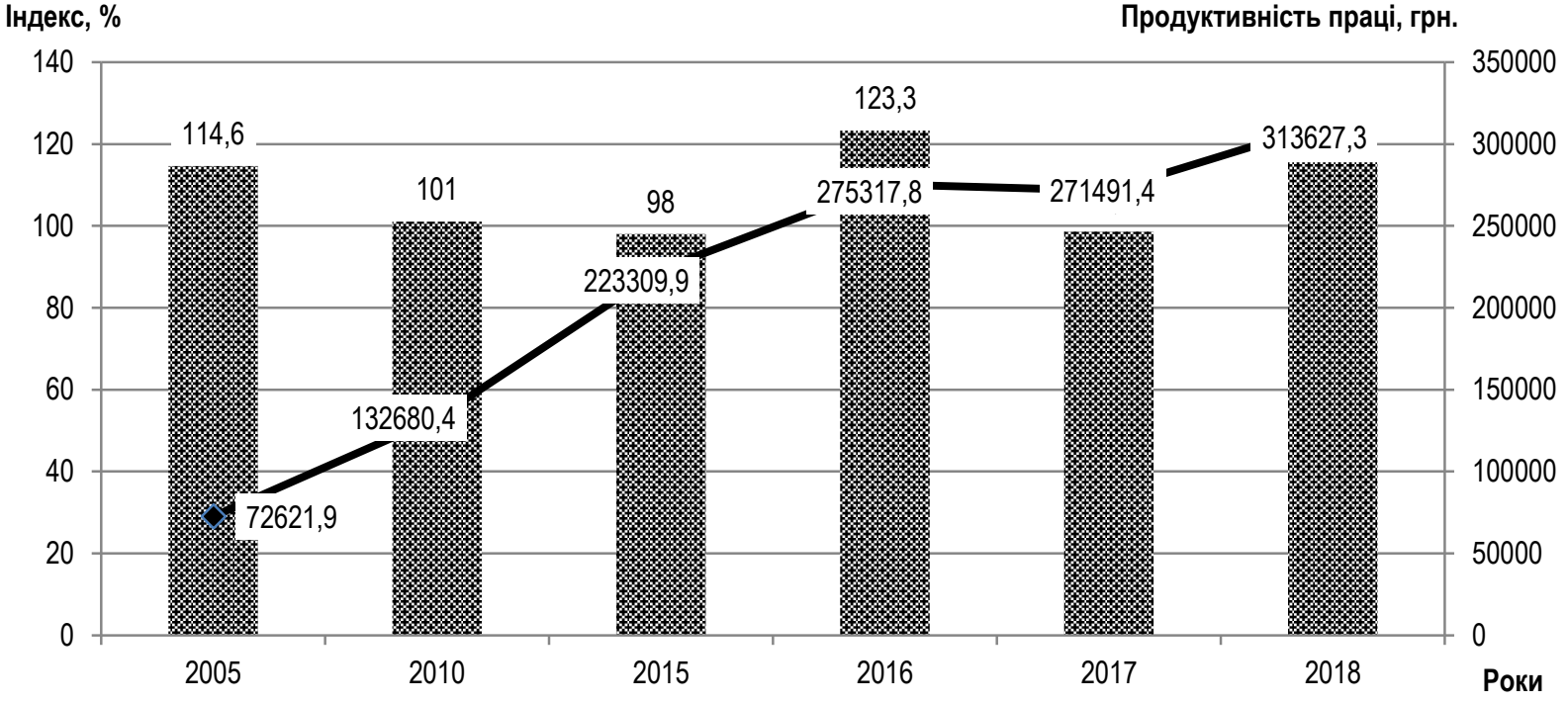

Рис. 5. Продуктивність праці та індекси ї̈ зміни в сільськогосподарських підприємствах України, 2005-2018 рр. Джерело: узагальнено автором за [9]

У 2018 р. продуктивність праці в сільськогосподарсь- | ких підприємствах України становила 313627 грн, що на да- 
ний момент часу складає близько 10 тис. євро на одного робітника. Позитивним є зростання продуктивності праці. Так, порівнюючи 2018 р. із 2005 р. продуктивність праці зросла в 4,3 рази. У 2018 р. порівняно із 2017 р. індекс зростання продуктивності праці становив $115,5 \%$.

Стратегія підвищення есрективності праці в аграрних підприємствах повинна ґрунтуватись на таких базових аспектаX:

- збалансований підхід до нарощування виробництва та продуктивності праці, який полягає у поєднанні економічного, соціального, екологічного ефектів та забезпеченні синергічного розвитку суб'єкта господарювання;

- орієнтація не лише на кількісні показники продуктивності праці, а й на якісні, враховуючи при цьому показники безпеки аграрної продукції;

- інноваційна орієнтація розвитку системи технологій в аграрному підприємстві;

- формування ефективної кадрової політики та узгодженість кадрової стратегії із корпоративною та функціональними стратегіями;

- посилення мотиваційного механізму, забезпечення випереджаючого зростання продуктивності праці, порівняно із темпами зростання матеріальних стимулів;

- стратегічний розвиток кадрового потенціалу, інтелектуалізація праці в аграрному секторі, впровадження стратегії безперервного навчання, підвищення кваліфрікації, у тому числі і за кордоном;

- удосконалення кадрової політики на державному рівні, зокрема посилення престижності праці в аграрному секторі, удосконалення нормативів праці, підтримка розвитку сільських територій та відповідної соціальної сфери.
Висновки. Персонал відіграє ключову роль у забезпеченні ефрективного розвитку суб'єкта господарювання. Ефективність праці визначається за допомогою низкою показників, які узагальнюють результати функціонування економічної системи та співвідносяться із затратами праці. На державному рівні для співставлення між країнами для оцінювання ефективності праці доцільно розглядати показники ВВП за паритетом купівельної спроможності в розрахунку на одну особу та людино-годину. За цими показниками в Європі лідирують Данія, Ірландія, Норвегія, Люксембург, Нідерланди, Франція.

Ефективність праці в розрізі країн суттєво залежить від галузей, у яких працюють працівники. Для країн-лідерів рейтингу за ефрективністю праці характерні низькі частки сільського господарства (менше 6 \%). Лідером за продуктивністю праці в сільському господарстві в Європі $€$ Данія (216,68 тис. євро на одного робітника), при цьому, частка сільського господарства в цій країні складає 2,186 \%. Продуктивність праці в Україні в середньому в 10 разів менша, ніж у Європі, при цьому, 18 \% населення працюють саме в цій сфері. Зростання продуктивності праці в сільськогосподарських підприємствах, яке спостерігається в останні роки, викликане впровадженням інтенсивних технологій та високопродуктивних виробничих потужностей. Основною стратегії підвищення ефективності праці в аграрних підприємствах має бути збалансований підхід до забезпечення економічної, соціально та екологічної ефективності.

Перспективи досліджень в даному напрямі полягають в обґрунтуванні організаційно-економічного механізму підвищення ефективності використання персоналу в аграрних підприємствах.

\section{Список використаної літератури:}

1. Петрова І. Л. Ринок праці: процес сегментації : монографія. Київ : УДПУ, 1996. 178 с.

2. Погорєлова Т. О. Аналіз факторів, які впливають на ефрективність праці персоналу підприємства. Вісник Національного технічного університету «Харківський політехнічний інститут». 2016. № 27 (1199). С. 17-21.

3. Рижих В., Морозова Н. Особливості структури зайнятості та проблеми якості трудового потенціалу на вітчизняному ринку праці:аспекти державного регулювання. Державне управління та місцеве самоврядування. 2018. Вип. 3(38). С. 84-92.

4. Маркіна І.А., Михайлов О.О. Формування кадрового потенціалу українських підприємств у сучасних реаліях. Економічний аналіз : зб. наук. праць: Тернопільський національний економічний університет. 2014. Том 17. № 2. С. 69-75.

5. Танасюк І., Орленко О. Основні напрями підвищення продуктивності праці персоналу в сучасних умовах. Науковий вісник Одеського національного економічного університету. 2018. № 11. С. 179-196.

6. Орленко О.М. Продуктивність праці як критерій ефективності інноваційної діяльності підприємства. Вісник Хмельницького національного університету 2011. № 2. Т. 2. С. 91-95.

7. Samoilyk lu., Zos-Kior M., Kuksa I., \& Storoška M. Methodology for assessing globalisation development of countries. Economic Annals-XXI. 2017. Volume 168, Issue 11-12. pp. 4-8.

8. Eurostat. Database. URL : https://ec.europa.eu/eurostat/data/database.

9. OECD (2019). Productivity-statistics. URL : https://www.oecd-library.org/employment/data/oecd-productivity-statistics/productivity-and-unit-labour-cost-by-industry-isic-rev-4-edition-2019_13a0f60a-en

10. Worldbank. URL :https://data.worldbank.org.

11. Сільське господарство України 2018: Статистичний збірник Відповідальний за вип. Прокопенко О.В. К. Державна служба статистики України. 2019. 235 с.

\section{References:}

1. Petrova I. L. (1996) Rynok pratsi: protses sehmentatsii [Labor market: the process of segmentation]. UDPU. Kyiv.

2. Pogorelova T.O. (2016) «Analysis of factors that affect the efficiency of the personnel of the enterprise». Visnyk Natsional'noho tekhnichnoho universytetu «Kharkivs'kyj politekhnichnyj instytut». no. 27 (1199). pp. 17-21.

3. Ryzhikh V. and Morozova N. (2018) «Features of the structure of employment and the problem of quality of labor potential in the domestic labor market: aspects of state regulation». Derzhavne upravlinnia ta mistseve samovriaduvannia. Issue 3 (38). pp. 8492.

4. Markina I. A. and Mikhailov O. O. (2014) «Formation of personnel potential of Ukrainian enterprises in modern realities». 
Ekonomichnyj analiz : zb. nauk. prats': Ternopil's'kyj natsional'nyj ekonomichnyj universytet; redkol. Volume 17. № 2. pp. 69-75.

5. Tanasyuk I. and Orlenko O. (2018) «The main directions of increasing staff productivity in modern conditions». Naukovyj visnyk Odes'koho natsional'noho ekonomichnoho universytetu. no. 11. pp. 179-196.

6. Orlenko O.M. (2011) Labor productivity as a criterion for the effectiveness of innovative activities of the enterprise. Visnyk Khmel'nyts'koho natsional'noho universytetu. no. 2. Volume. 2. pp. 91-95.

7. Samoilyk lu., Zos-Kior M., Kuksa I., \& Storoška M. (2017) Methodology for assessing globalisation development of countries. Economic Annals-XXI. Volume 168, Issue 11-12. pp. 4-8.

8. Eurostat. Database. URL : https://ec.europa.eu/eurostat/data/database.

9. OECD (2019). Productivity-statistics. URL : https://www.oecd-library.org/employment/data/oecd-productivity-statistics/productivity-and-unit-labour-cost-by-industry-isic-rev-4-edition-2019_13a0f60a-en

10. Worldbank. URL :https://data.worldbank.org.

11. Agricultural statistics for 2018. Editor Prokopenko O.V. State Statistics Service of Ukraine. K. 2019. 235 p.

Berezina L.M., Dr, Professor, Poltava State Agrarian Academy (Poltava, Ukraine)

Samoilyk lu.V., Dr, Professor, Poltava State Agrarian Academy (Poltava, Ukraine)

Bodryi Ya.A., PhD student of economic science, Poltava State Agrarian Academy (Poltava, Ukraine)

Labor efficiency in agricultural enterprises: indicators, trends, increasing strategy.

The article has been further developed the recommendations for increasing labor efficiency in agricultural enterprises. The peculiarities and role of labor in the agricultural sector have been revealed. Various conceptual approaches to assessing labor efficiency, indicators and factors of its provision have been considered. It has been substantiated that labor productivity not only characterizes the efficiency of the enterprise's personnel, but also shows the general results of social development and the country's rating on a global scale.

It has been substantiated that a significant labor productivity increase is positive in terms of economic efficiency; however, such trends have negative social consequences, as the need for staff decreases. To assess the personnel use effectiveness of the worldwide, indicators such as the production of GDP at purchasing power parity per capita and GDP at purchasing power parity per person-hour have been evaluated. Leaders among European countries in terms of labor efficiency have been identified. These include Ireland, Norway, Luxembourg, France, the Netherlands, Denmark, Switzerland, Sweden, Austria and the United Kingdom.

A research of labor efficiency trends in agriculture has been carried out. It has been found that in 2019 the share of workers employed in agriculture on average in the world was $26.9 \%$, which is 16.8 percentage points less than in 1991. The share of agricultural employment in European countries, which are leaders in the level of labor efficiency, ranges from $0.961 \%$ in Belgium to $6.873 \%$ in Lithuania, the highest labor productivity in agriculture is observed in Denmark - 216.68 million EUR per worker, labor productivity in agricultural enterprises of Ukraine has been twice lower than in Latvia and 20 times lower than in Denmark.

The main strategy to increase labor efficiency in agricultural enterprises should be a balanced approach to ensuring economic, social and environmental efficiency.

Key words: labor efficiency, labor productivity, GDP at purchasing power parity, sectoral structure of employment, agricultural enterprise, strategy to increase labor efficiency.

Дата надходження до редакції: 20.10.2019 p. 